\title{
Response of 1-Methycyclopropene on Postharvest Quality of Local Soursop (Annona muricata L.)
}

(Gerak Balas 1-Metisiklopropena ke atas Kualiti Lepas Tuai Durian Belanda Tempatan (Annona muricata L.))

\author{
Lem Ming Siang*, Phebe Ding \& Mahmud TengKu Muda Mohamed
}

\begin{abstract}
Soursop (Annona muricata L.), a climacteric fruit which is rich in bioactive compounds for use its in medicine. It produces an aromatic, sweet-sour and pleasant taste. However, there is a limitation in the fruit being able to reach distant markets. Its quick ripening and accentuated softening properties make it difficult to handle without damage and shorten its postharvest life. In order to reduce lost value during storage life, this study aims to investigate the effect of 1-Methylcyclopropene (1-MCP) treatment on the fruit's postharvest life including its physiological and physiochemical characteristics. Selected soursop fruits were harvested at 16 weeks after pollination and treated with various concentrations of $1-\mathrm{MCP}(0,400,800$ and $1200 \mathrm{~nL} / \mathrm{L})$ at $15^{\circ} \mathrm{C} \pm 3^{\circ} \mathrm{C}$ for $24 \mathrm{~h}$ and subsequently being stored at ambient temperature $\left(25^{\circ} \mathrm{C} \pm 3{ }^{\circ} \mathrm{C}\right)$. Observations on various physical, physiological, biochemical and antioxidants parameters were recorded at a two-day intervals 6 days of storage. The results showed that respiration rate and ethylene production in 1-MCP treated fruit were lower than those in the control batches. Further, the pulp of 1-MCP treated fruits remained firm and colour was retained throughout the observation period. Soursop treated at different 1-MCP concentration (0, 400, 800 and $1200 \mathrm{~nL} / \mathrm{L}$ ) showed that fruit treated with $400 \mathrm{~nL} / \mathrm{L}$ had better ripe fruit quality. In addition, 1-MCP treated fruits were able to normally soften at day six after storage. However, antioxidant capacity, total phenolic content, and total flavonoid content of fruits from all treatments were found inconsistent during storage.
\end{abstract}

Keywords: Colour; firmness; soursop; 1-MCP

\section{ABSTRAK}

Durian belanda (Annona muricata L.) ialah buah klimakterik yang kaya dengan sebatian bioaktif untuk kegunaan perubatan. Ia mengeluarkan aroma, rasa manis-masam dan sedap. Walau bagaimanapun, pemasaran yang jauh menjadi satu cabaran kerana ia cepat masak dan menonjolkan sifat-sifat lembik yang menjadikannya sukar untuk diproses tanpa kerosakan dan dipendekkan jangka hayat lepas tuai. Untuk mengurangkan kehilangan nilai sepanjang tempoh penyimpanan, kajian ini bertujuan untuk mengenal pasti kesan rawatan 1-Metisiklopropena (1-MCP) terhadap jangka hayat penyimpanan lepas tuai, fisiologi dan biokimia durian belanda. Buah durian belanda terpilih dituai pada umur 16 minggu selepas pendebungaan dan dirawat dengan 1-MCP pada kepekatan (0,400, 800 dan $1200 \mathrm{~nL} / \mathrm{L})$ di bawah suhu $15^{\circ} \mathrm{C}$ $\pm 3^{\circ} \mathrm{C}$ selama 24 jam dan kemudian disimpan pada suhu ambien $\left(25^{\circ} \mathrm{C} \pm 3{ }^{\circ} \mathrm{C}\right)$. Pemerhatian terhadap fizikal, fisiologi, biokimia dan antioksidan dicatat selang dua hari selama 6 hari penyimpanan. Kadar respirasi dan pengeluaran etilen dalam buah dengan rawatan 1-MCP adalah lebih rendah daripada kawalan. Pulpa bagi buah yang dirawat 1-MCP tetap teguh dan warna kekal sepanjang tempoh pemerhatian. Hasil rawatan durian belanda pada beberapa kepekatan 1-MCP menunjukkan buah yang dirawat dengan $400 \mathrm{~nL} / \mathrm{L}$ mempunyai kualiti kemasakan buah yang lebih baik. Di samping itu, buah yang dirawat 1-MCP dapat berubah menjadi lembut secara normal selepas hari ke enam. Walau bagaimanapun, kandungan antioksidan, fenolik dan flavonoid buah bagi semua rawatan didapati tidak konsisten semasa penyimpanan.

Kata kunci: Durian belanda; keras; warna; 1-MCP

\section{INTRODUCTION}

Soursop (Annona muricata L.), a member of the Annonaceae family is a small, evergreen tree widely cultivated from central America and is now widespread in the tropics and subtropics (Geurts 1981). In Malaysia, soursop is still considered as a minor fruit crop, with only 356.7 hectares of cultivation area, yielding a total of 1,470.4 Mt of production (DOA 2015). In Malaysia soursop, is mainly cultivated for domestic consumption. Nevertheless, it posseses great potential to be developed commercially because of its inherent acetogenins confer protection against cancer (Jiménez et al. 2014). Furthermore, promising retail prices for soursop provides great opportunity to growers for cultivation. Thus, the fruit can be extensively cultivated in Malaysia to fulfil the projected demand from domestic and foreign markets. The major bottlenecks in the local soursop value chain is the lack of improved postharvest technology as the crop is highly perishable when it turns soft and bruised easily. As a typical climacteric fruit, soursop was characterized 
by a rapid increase in the rate of ethylene biosynthesis at the beginning of the ripening process (Bruinsma \& Paul 1984; Worrell et al. 1994). The presence of middlemen, known as collectors in the market chain add no value to the produce, thus, limit the potential of small scale processing factories or firms. Fruit quality deterioration is caused by several factors such as intrinsic characteristics of the fruit itself and storage conditions. The means to prolong fruit ripening process as proposed by Abdi et al. (1998) can be undertaken by ultilising inhibtitors of ethylene production and actions. The use of 1-Methycyclopropene (1-MCP), as ethylene inhibitor in preventing the physiological action on ethylene has been gaining its popularity in recent decades (Sisler \& Serek 1997). The application of 1-MCP has shown tremendous potential in maintaining the quality of various fruits, vegetables, and flowers during storage (Blankenship $\&$ Dole 2003; Jiménez 2015). The mechanism was further elaborated that $1-\mathrm{MCP}$ binds irreversibly to ethylene receptors, and ethylene sensitivity is recovered through the appearance of new ethylene receptors (Blankenship \& Dole 2003). Studies on species belonging to the Annonaceae family have been reported the positive influence of 1-MCP on fruit storage life and some aspects of fruit quality, particularly in Latin American countries (Benassi et al. 2003; Espinosa et al. 2012; Hofman et al. 2001; Li et al. 2009; Lima et al. 2003; Moreno-Hernandez et al. 2014). Lima et al. (2010) who first a reported on the effect of an ethylene inhibitor, 1-Methylcyclopropene (1-MCP) on soursop fruit and stated that some delays in naturally pollinated fruit ripening was observed when stored at room temperature or under cooling, but the duration is relatively short when compared to other fruits. The use of this ethylene inhibitor improved the preservation and quality of soursop, including lower weight loss, colour retention, titratable acids (TA) and soluble solids concentration (SSC). Espinosa et al. (2012) showed that soursop fruit treated with 1-MCP prolonged storage life while maintaining the required quality aspects. Recent studies have also shown that the combination of 1-MCP and wax emulsions can preserve nutritional composition and antioxidant activity of soursop (Moreno-Hernández et al. 2014). However, no research has been reported relating to postharvest studies on hand-pollinated soursop on the effect of 1-MCP in extending its storage life, fruit softening and nutritional composition including ascorbic acid, antioxidant capacity and total phenolic content. Hence, the main objective of this study was to evaluate the effects of 1-MCP in delaying the ripening process in relation to the postharvest quality of soursop during the storage period.

\section{MATERIALS AND METHODS}

\section{PLANT MATERIALS}

Soursop fruits were harvested at 16 weeks after pollination from commercial farm from Simpang Renggam, Johor

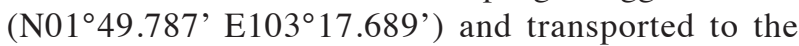
Postharvest Laboratory, Department of Crop Sciences,
Faculty of Agriculture, UPM where the analyses were undertaken. The determination of ethylene production and respiration rate were conducted and recorded in the Postharvest Laboratory, MARDI within $3 \mathrm{~h}$.

\section{1-MCP TREATMENT AND STORAGE CONDITION}

The fruits were placed into four sealed $100 \mathrm{~L}$ box plastic containers $(780 \times 470 \times 375 \mathrm{~mm})$ and treated with 0,400 , 800 , and $1200 \mathrm{~nL} / \mathrm{L}$ of $1-\mathrm{MCP}$ (1-Methylcyclopropene), respectively, maintained at a cold room temperature of $15^{\circ} \mathrm{C} \pm 3^{\circ} \mathrm{C}$ for $24 \mathrm{~h}$. The required concentrations of $1-\mathrm{MCP}$ were obtained from SmarthFresh ${ }^{\mathrm{TM}}$ powder (AgroFresh Inc., $0.14 \%$ a.i.) and was added into $40^{\circ} \mathrm{C}$ distilled water. Concentrations of 1-MCP were calculated according to the concentration of the active ingredient. On the following day, the plastic containers were opened and the fruits were stored at ambient temperature $\left(25^{\circ} \mathrm{C} \pm 3^{\circ} \mathrm{C}\right)$. The physicochemical quality characteristics of the fruit such as ethylene production, respiration rates, water loss, fruit colour, fruit firmness, soluble solids content (SSC), $\mathrm{pH}$, ascorbic acid and titratable acidity (TA) were assessed every two days.

\section{DETERMINATION OF ETHYLENE PRODUCTION AND RESPIRATION RATE}

Ethylene $\left(\mathrm{C}_{2} \mathrm{H}_{4}\right)$ production and carbon dioxide $\left(\mathrm{CO}_{2}\right)$ production rates were measured by incubating fruit in a 6.0 L airtight jar for $2 \mathrm{~h}$ at room temperature. The gas samples were withdrawn through a septum on the top using a $1 \mathrm{~mL}$ gas-tight syringe. A $1 \mathrm{~mL} \mathrm{C}_{2} \mathrm{H}_{4}$ gas sample was injected into a gas chromatograph (Clarus-500, Perkin Elmer, USA) which is equipped with a flame ionization detector (FID) and $1 \mathrm{~mL} \mathrm{CO}{ }^{2}$ gas sample was injected into a gas chromatograph (Clarus-680, Perkin Elmer, USA) which is equipped with a thermal conductivity detector (TCD). Ethylene production rate is expressed as $\mu \mathrm{L} \mathrm{kg}^{-1} \mathrm{hr}^{-1}$ and $\mathrm{CO}^{2}$ production rate is expressed as $\mathrm{mL} \mathrm{kg}^{-1} \mathrm{hr}^{-1}$.

\section{DETERMINATION OF WEIGHT LOSS}

Percentage water loss is the different between the initial and final weight of a fruit. A weight balance was used to measure the weight of each fruit. The water loss percentage was calculated as:

$$
\% \text { water loss }=\frac{\text { The initial fruit weight }- \text { the final fruit weight }}{\text { The initial fruit weight }}
$$

\section{DETERMINATION OF PEEL COLOUR}

Peel colour was measured using a Minolta CR-300 chroma meter (Minolta Corp., Japan), obtaining the CIE color data (lightness $\left(\mathrm{L}^{*}\right)$, chroma $\left(\mathrm{C}^{*}\right)$ and hue $\left(\mathrm{h}^{\circ}\right)$ ) according to Ding and Darduri (2009). Measurements were made at the top, middle and bottom part of the peel and the results were expressed as averages. 


\section{DETERMINATION OF FRUIT FIRMNESS}

Fruit firmness was measured using a penetrometer (Model Instron 5543, INSTRON Co., USA) equipped with a cylindrical flat-surfaced plunger (6 $\mathrm{mm}$ diameter). The Instron was used simultaneously with an Intron Merlin Software version M12-1366-EN. Firmness was recorded from three different parts of fruit - top, middle and bottom, and means were expressed as newtons $(\mathrm{N})$.

\section{DETERMINATION OF TITRATABLE ACIDITY (TA) ASCORBIC ACID (AA), SOLUBLE SOLIDS CONCENTRATION (SSC) AND PH}

Titratable acidity (TA) and ascorbic acid (AA) content was determined according to titration method by Ranganna (1977) and the results were expressed as \% malic acid and $\mathrm{mg}$ per $100 \mathrm{~g}$, respectively. The balance of juice from TA determination was used to measure $\mathrm{pH}$ value. The $\mathrm{pH}$ was measured by using a pH meter (GLP 21, Crison, Barcelona). The $\mathrm{pH}$ meter was calibrated with buffer at $\mathrm{pH} 4.0$ and 7.0 before being used. SSC was determined using a digital refractometer (Model PR-32 $\alpha$, Atago ${ }^{\circledR}$, Japan) and values were expressed in Brix (\%).

\section{EXTRACTS FOR FRUIT SAMPLES}

To analyse the total phenolic and antioxidant activity, fruit extracts in methanol were prepared using the method described by Thaipong et al. (2006) with some modifications. Briefly, three grams of pulp of each fruit were chopped and homogenized with $25 \mathrm{~mL}$ of absolute methanol using a blender (MX-799S, Panasonic, Malaysia) and filtered through cotton. The filtrate was centrifuged using a centrifuge (Thermo Scientific, model Heraeus Megafuge 8R) at 8,000 rpm for $40 \mathrm{~min}$. The methanolic supernatants were stored at $-20^{\circ} \mathrm{C}$ until further analysis.

\section{DPPH ASSAY}

The antioxidant activity was determined using DPPH (1,1-diphenyl-2-picrylhydrazyl) free radical scavenging activity assay according to the method of Lafka et al. (2007) with minor modifications. DPPH solution at $100 \mu \mathrm{M}$ in methanol was prepared and $0.1 \mathrm{~mL}$ of sample was added to $3.9 \mathrm{~mL}$ of DPPH solution prepared in methanol $(0.025$ $\mathrm{g} / \mathrm{L})$. The reaction mixture was kept in the dark at ambient temperature for $30 \mathrm{~min}$. The absorbance was measured at $515 \mathrm{~nm}$ using a spectrophotometer (Thermo Scientific ${ }^{\mathrm{TM}}$ Multiskan $^{\mathrm{TM}}$ GO Microplate spectrophotometer) with a programmed $30 \mathrm{~s}$ shake cycle. Simultaneously, the absorbance at $515 \mathrm{~nm}$ of the blank sample $(0.1 \mathrm{~mL}$ methanol $+3.9 \mathrm{~mL}$ methanolic solution of DPPH) against methanol was measured. The percentage of inhibition of the DPPH radical was calculated according to the following formula:

$$
\text { Inhibition of DPPH }(\%)=\frac{\left(\mathrm{A}_{0}-\mathrm{A}\right)}{\mathrm{A}_{0}} \times 100
$$

where $A_{0}$ is the absorbance of DPPH radicals without sample; and $\mathrm{A}$ is the final absorbance of DPPH radicals with sample.

\section{TOTAL PHENOLIC ASSAY}

The total phenolic compound of soursop fruit methanolic extracts was determined by Folin Ciocalteu reagent according to the standard method (Loizzo et al. 2012) with slight modifications where a $0.1 \mathrm{~mL}$ sample was added to $1.6 \mathrm{~mL}$ distilled water and $0.1 \mathrm{~mL}$ Folin-Ciocalteu reagent. The tube was covered with aluminium foil, mixed thoroughly and incubated at $25^{\circ} \mathrm{C}$ for $10 \mathrm{~min}$ and then $0.6 \mathrm{~mL} 20 \%(\mathrm{w} / \mathrm{v})$ sodium carbonate $\left(\mathrm{Na}_{2} \mathrm{CO}_{3}\right)$ was added into the solution before further incubated at $40^{\circ} \mathrm{C}$ for $20 \mathrm{~min}$, with intermittent shaking. The absorbance was measured at $760 \mathrm{~nm}$ using a spectrophotometer (Thermo Scientific ${ }^{\mathrm{TM}}$ Multiskan ${ }^{\mathrm{TM}}$ GO Microplate spectrophotometer). Amount of TPC was calculated from standard curve of gallic acid ( 0.05 to $0.25 \mathrm{mg} / \mathrm{mL})$. The result was expressed as Gallic Acid Equivalents (GAE) in milligrams per $100 \mathrm{~g}$ of fresh weight (FW).

\section{TOTAL FLAVONOID ASSAY}

Total flavonoid content was determined using aluminium chloride colorimetric method. Total flavonoid of soursop was measured in a similar way to that as described by Barreca et al. (2011) with slight modifications where 0.1 mL extract, $2.0 \mathrm{~mL}$ distilled water and $0.15 \mathrm{~mL} \mathrm{5 \% (w/v)}$ sodium nitrite $\left(\mathrm{NaNO}_{2}\right)$ were mixed for $5 \mathrm{~min}$ before vortexed (IKA® Vortex. Genius 3). Then, $0.15 \mathrm{~mL}$ of $10 \%(\mathrm{w} / \mathrm{v})$ aluminium chloride $\left(\mathrm{AlCl}_{3}\right.$ was added and the mixture was vortexed for $1 \mathrm{~min}$. Afterward, $1 \mathrm{~mL}$ of 1.0 M sodium hydroxide $(\mathrm{NaOH})$ was added and stirring was resumed for $1 \mathrm{~min}$. The absorbance was measured at $490 \mathrm{~nm}$ using a spectrophotometer (Thermo Scientific ${ }^{\mathrm{TM}}$ Multiskan $^{\mathrm{TM}}$ GO Microplate spectrophotometer). Amount of total flavonoid was calculated from standard curve of quercetin (0 to $0.5 \mathrm{mg} / \mathrm{mL}$ ). The result was expressed as quercetin equivalents $(\mathrm{QE})$ in milligrams per $100 \mathrm{~g}$ of fresh weight.

\section{STATISTICAL ANALYSIS}

Fruits were evaluated 0,2, 4 and 6 days after harvest. The experiment was conducted in a Randomized Completely Block Design (RCBD) organized as a single factorial arrangement of treatments (4 concentration $\times 4$ storage days) and four replications ( 3 fruits per replication). The data was compared using analysis of variance (ANOVA) using Statistical Analysis System (SAS), version 9.4 (SAS Institute Inc.; Cary, NC, USA). Mean separations were performed by Duncan's new multiple range test (DMRT), at $p \leq 0.05$. 


\section{RESULTS AND DISCUSSION}

\section{ETHYLENE PRODUCTION AND RESPIRATION RATE}

The results showed that a lower rate of ethylene production during the first four days storage duration at $25^{\circ} \mathrm{C} \pm 3^{\circ} \mathrm{C}$ followed by a higher rate of ethylene production in 1-MCP treated fruits which shared a similar trend but much higher rate of ethylene production in control fruits (Figure 1(a)). Subsequently, the ethylene production in untreated fruit experienced a sharp increase with prolonged storage and reached the peak by the end of storage. From day 2 until day 6 , the rates of ethylene production of 1-MCP treated fruits were lower than that of the control fruits (Figure 1(a)). This indicated that ethylene production rates for fruits treated with 1 -MCP held at $25^{\circ} \mathrm{C} \pm 3^{\circ} \mathrm{C}$ were suppressed. The suppression of climacteric peak in 1-MCP treated fruit is ascribed to its irreversibly binding to ethylene receptors (Sisler \& Serek 1997). It can also due to the ability of 1-MCP interfering with autocatalytic ethylene production (Lalel et al. 2003) or also to its competition with ethylene for binding sites (Blankenship \& Dole 2003). The application of 1-MCP suppressed ethylene production after the 4th day, with reduction of ethylene production at 800 and 1200 $\mathrm{nL} / \mathrm{L}$ 1-MCP treated fruits compared to control fruits (Figure 1(a)). This can be interpreted as 1-MCP induced delay of the ethylene production. These results were complemented to Espinosa et al. (2013) who also found a delayed ethylene 1 -MCP treated soursop fruits. The effect of 1-MCP on delaying and reduction in ethylene production were also reported in other climacteric fruits such as cherimoya ( $\mathrm{Li}$ et al. 2009), avocado (Zhang et al. 2011), mangosteen (Piriyavinit et al. 2011) and mango (Razzaq et al. 2016). Ethylene production during fruit ripening was inhibited when the activities of 1-aminocyclopropane carboxylic acid oxidase (ACO), 1-aminocyclopropane carboxylic acid synthase (ACS) and 1-aminocyclopropene-1-carboxylic acid (ACC) (Dong et al. 2001; Li et al. 2011; Piriyavinit et al. 2011) took place.

Respiration rates of 1-MCP treated fruits increased slightly along the first four days of storage followed by a rapid increase until the sixth day. Moreover, the effect of 1-MCP on respiration rate was in a concentration dependent manner. Compared with the control, the respiration rate was decreased by $19.5 \%$ on fruits treated with $1200 \mathrm{~nL} / \mathrm{L}$ 1-MCP (Figure 1(b)). The respiration rate has been reported an increase with ripening for all climacteric fruits and there is no exception for soursop (Kader 1997). According to Blanke (1991) the trend of increase in ethylene and respiration is functional in order to provide ATP and substrates for various anabolic processes associated with fruit ripening. Lower respiration rates observed for treated fruits suggested that $1-\mathrm{MCP}$ treatment can delay ripening process by decreasing respiration rate. Soursop treated with $400 \mathrm{~nL} / \mathrm{L} 1-\mathrm{MCP}$ was significantly delayed and inhibited the appearance of the peak of respiration rate and ethylene production, which is similar to finding with mexico cultivar soursop (Espinosa et al. 2013).
This is a typical situation for climacteric fruits and was also reported for 'Honey' peaches (Gang et al. 2015) and 'Maria Aurelia' nectarines (Özkaya et al. 2016).

\section{WEIGHT LOSS}

The results indicated that 1-MCP had no significant effect in reducing water loss from soursop fruits. Higher relative humidity under the storage may contribute to the low rate of weight loss. No further observation was carried out after the sixth day of storage because most of the fruits turned rotten and fruits surface was pitted from that day onwards thus rendering the fruits for further observation. It was part of the transition from physiological maturity to senescence (Lima et al. 2006).

\section{PULP FIRMNESS}

The control and 1-MCP treated fruit demonstrated a similar declining trend in firmness during storage for 6 days (Figure 2(a)). The results showed that significantly higher pulp firmness was exhibited by the soursop fruits treated with 1-MCP as compared to control fruits. Application of 1-MCP treatment significantly delayed fruits' softening. Similar results were also obtained in other fruits, including cherimoya (Li et al. 2009), mangosteen (Piriyavinit et al.

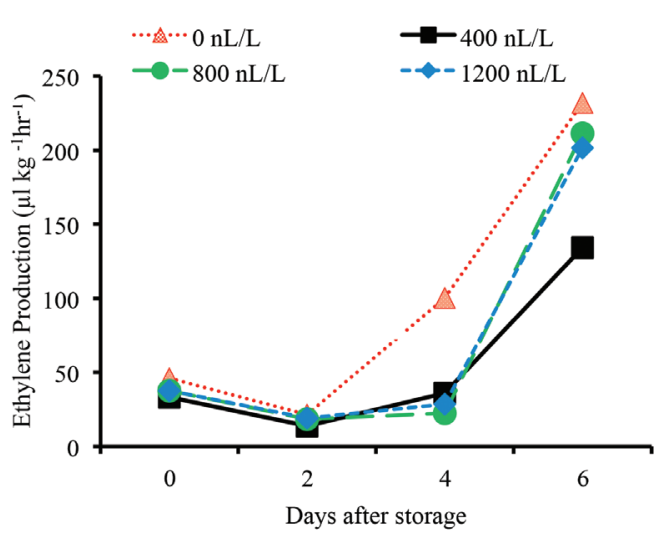

a)

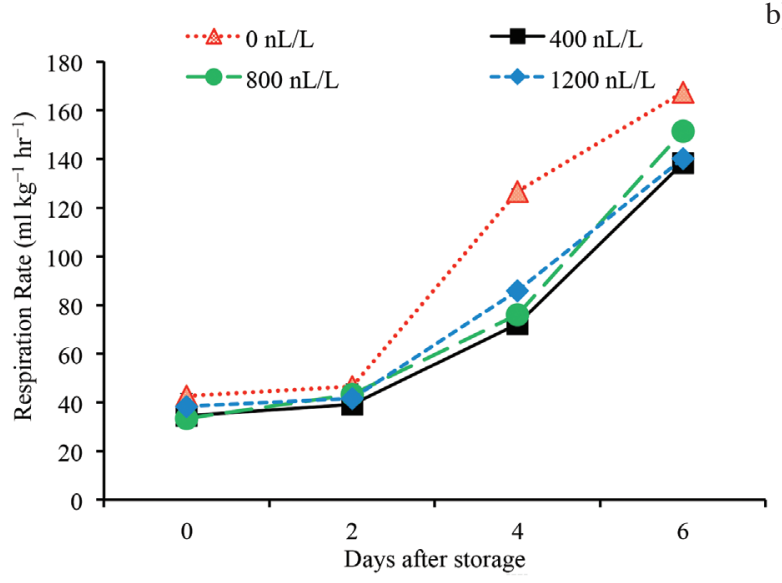

FIGURE 1. Ethylene production (a) and respiration rate (b) of soursop treated with 1-MCP during day after storage

b) 
2011), banana (Pongprasert \& Srilaong 2014) and 'Abate Fetel' pear (Vanoli et al. 2016). However, firmness of fruits rapidly decreased after storage at ambient temperature began for all treatments, indicating 1-MCP is helpful in slowing down fruit softening but absolutely not a ripening inhibitor. In soursop, firmness indicates the stage of ripeness, especially in reflecting the edible stage. Fruit softening along ripening undergone deconstruction of cell wall and middle lamella with modifications to the polysaccharide with the aid of enzymes and proteins (Brummell 2006; Brummell \& Harpster 2001) as resembling by avocado, banana and papaya fruit (Ahmad et al. 2013; Jeong et al. 2002; Lohani et al. 2004). The reduction in soursop fruits softening events with $1-\mathrm{MCP}$ treatment may be attributed to reduction in ethylene production with application of 1-MCP (Figure 1(a)) as reported by Khan and Singh (2007).

\section{SOLUBLE SOLIDS CONCENTRATION}

SSC of soursop fruits increased constantly during storage duration (Figure 2(b)). A significantly lower SSC was exhibited by the soursop fruits treated with $400 \mathrm{~nL} / \mathrm{L}$ 1-MCP as compared to fruits treated with 0,800 and 1200 $\mathrm{nL} / \mathrm{L}$ during the entire ripening period. Fruits treated with 800 and $1200 \mathrm{~nL} / \mathrm{L} 1-\mathrm{MCP}$ gave similar effect to SSC of fruits (Figure 2(b)). The increase in soluble solids concentration is coincides with the observed decrease in firmness (Figure 2(a)) along the storage periods. SSC content is a quintessential compound found in ripe fruit. It consists of soluble sugar from starch degradation during ripening process and thus give sweetness and flavour to edible fruit (Wills et al. 2007). The increase in SSC could due to the conversion of starch into soluble sugars, such as sucrose, fructose and glucose. The same mechanism also occurred in Annonaceae family which concurred by Paull et al. (1983) in soursop and by Vishnu Prasanna et al. (2000) in custard apple. This study showed that fully ripe untreated soursops, reached a maximum of $18.27 \%$ SSC after six days of storage, while fruits treated with 400 $\mathrm{nL} / \mathrm{L}$ only attained a maximum of $16.98 \%$ SSC. The relation continued with the application of higher concentration of $1-\mathrm{MCP}$, with $800 \mathrm{~nL} / \mathrm{L}$ reaching a maximum $18.29 \%$ SSC and $1200 \mathrm{~nL} / \mathrm{L} 16.92 \%$ of SSC. Current finding was in agreement with previous study (Lima et al. 2006) that reported an increased in the hydrolysis of starch and pectin of 'Crioula' soursop at three days after storage at $26.3 \pm 0.6^{\circ} \mathrm{C}$. This indicated that 1 -MCP effectively delay in the production of SSC which probably due to the slowing down metabolism activities, hence, retarding the ripening process. This result is consistent with the findings of Espinosa et al. (2013) who reported that 1-MCP treated Mexican soursop had lower value of SSC than control during the storage period.

\section{pH AND TITRATABLE ACIDITY}

The result showed that fruit $\mathrm{pH}$ was significantly affected by the concentration of 1-MCP. Treated fruit indicated a much lower value of fruit $\mathrm{pH}$ compared with untreated fruit. The higher $\mathrm{pH}$ is presented by treated fruit compared to control fruit (Figure 2(c)). Among the 1-MCP treatments, the lowest concentration $(400 \mathrm{~nL} / \mathrm{L})$ showed the highest $\mathrm{pH}$, whereas the highest concentration $(1200 \mathrm{~nL} / \mathrm{L})$ showed the lowest $\mathrm{pH}$. During storage period the titratable acid (TA) of soursop increased gradually, slightly more in the control than in the 1-MCP treated fruit (Figure 2(d)). The rise in TA in the soursop was concomitant with the decrease in the $\mathrm{pH}$ value (Paull 1982). In general, higher acid levels in fruit will give lower $\mathrm{pH}$ values and vice versa. Whereas, a slow gradual increase of TA of fruits during first two days of storage took place, followed by a gradually increase until the fourth day. From day 4 to 6 , a slight increase in TA was observed. These relationships indicated that TA was lower at the initial ripening stage and increased during the ripening process. However, the value decreased slowly until the overripe stage as storage advanced. The predominant acid in soursop, malic acid which was developed during harvesting stage (GonzálezAgüero et al. 2016), may have contributed to the increase in TA in soursop (Paull et al. 1983). In the present study, TA increased after the 2 days of storage when the consumption of organic acids such as malic acids and citric acids substrates take place in the respiratory processes (Wills et al. 1998). The result showed that increase of TA values is more rapid in untreated fruits compared to fruits treated with 1-MCP. This indicate the effectiveness of 1-MCP in slowing down the respiration rate as well as metabolism mechanism of soursop.

\section{PEEL COLOUR}

As the ripening progressed, overall values for $\mathrm{L}^{*}$ were significantly increased while values of $\mathrm{C}^{*}$ and $\mathrm{h}^{\circ}$ were significantly reduced in comparison to the initial day (Figure 3(a), 3(b) \& 3(c)). 1-MCP treated fruits exhibited lower value of $\mathrm{L}^{*}$ and $\mathrm{C}^{*}$ but retained high value of $\mathrm{h}^{\circ}$ on fruit peel throughout the ripening period during storage compared to untreated fruits. Control fruit exhibited significant yellow green colour during storage. At the same time, fruit treated with 1-MCP remained significantly greener and retained of lightness thus resulted a delayed ripening process in soursop. Soursop fruits treated with $400 \mathrm{~nL} / \mathrm{L} 1-\mathrm{MCP}$ showed greater delay in colour change than others concentrations of 1-MCP. Color change is associated with an increase of ethylene. The delay in the production of colour change in these fruits is attributed to the effect of 1-MCP, which coincides with lower respiration and ethylene production (Figure 1(a) \& 1(b)). This is in agreement with previous reports that $1-\mathrm{MCP}$ prevented or delayed chlorophyll degradation and various types of color changes in a wide range of crop species during storage. Degreening of 'Brazil' banana was inhibited by 1-MCP after 20th day of storage (Zhu et al. 2015). This was also found to be true in 'Sekaki' papaya (Razali et al. 2012), 'Kampuchea' guava (Ding \& Ong 2010) and avocado (Woolf et al. 2005). 
a)

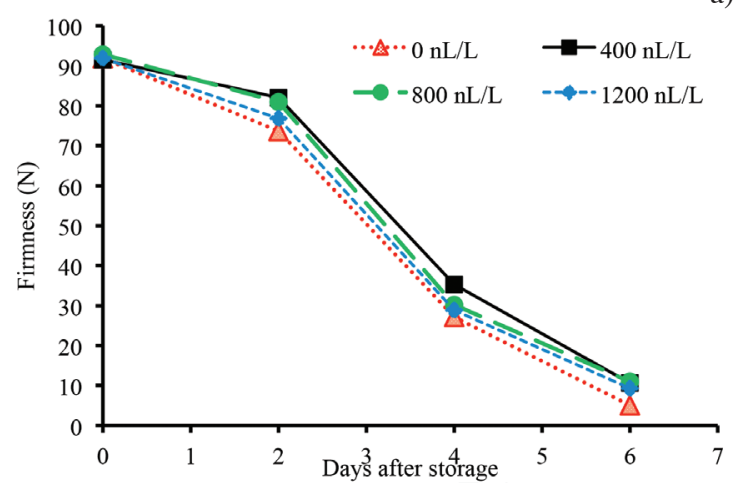

b)

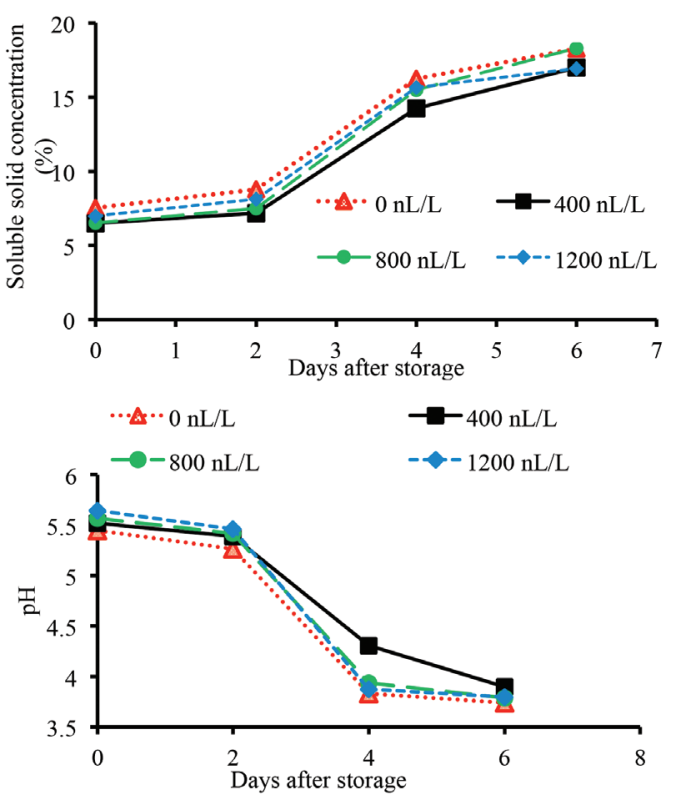

d)

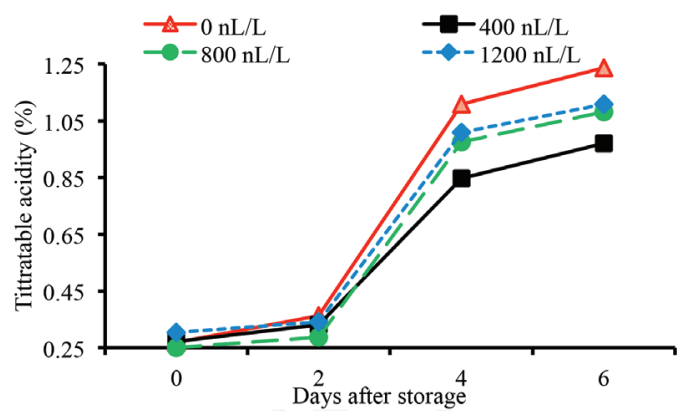

FIGURE 2. Firmness (a), soluble solids concentration (b), $\mathrm{pH}$

(c) and titratable acidity (d) of soursop treated with 1-MCP during day after storage

\section{ASCORBIC ACID CONTENT}

All concentrations at 400,800 and $1200 \mathrm{~nL} / \mathrm{L}$ of $1-\mathrm{MCP}$ treated soursop showed lower ascorbic acid content than control (Figure 4(a)). Obviously, 1-MCP induced delay in ripening by prolonging the oxidation of ascorbic acid in soursop. The result of present study was in accordance to the work of Liu et al. (2015), which they reported concentration of ascorbic acid was lower in 1-MCP treated pear than in untreated controls after ten days at $20^{\circ} \mathrm{C}$.
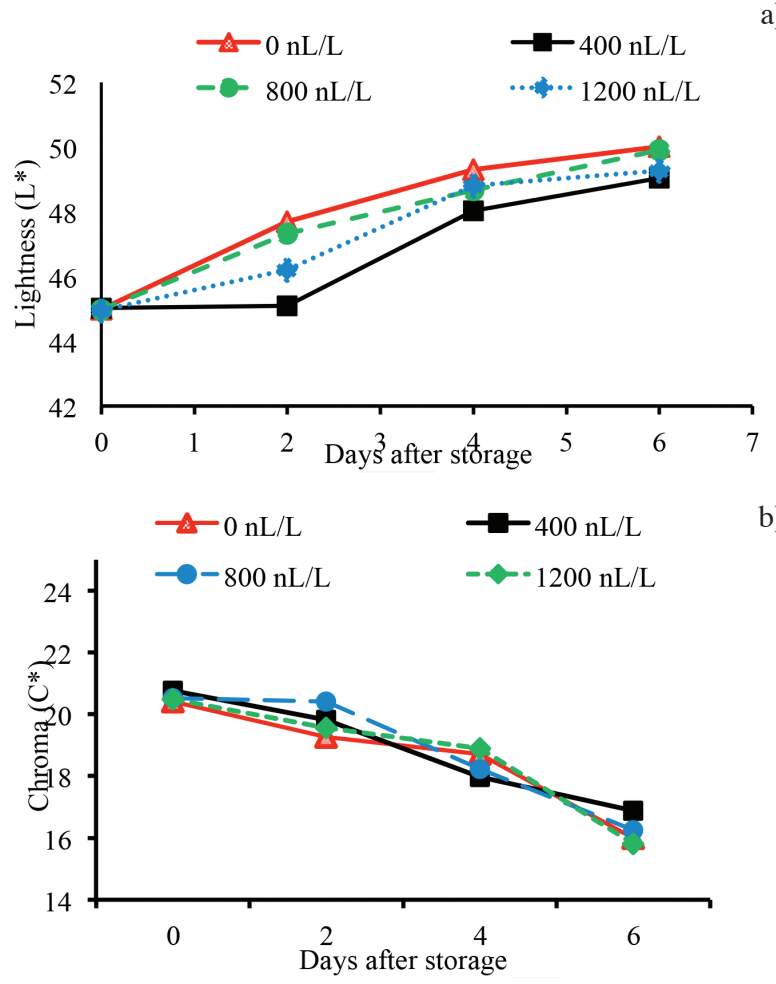

b)

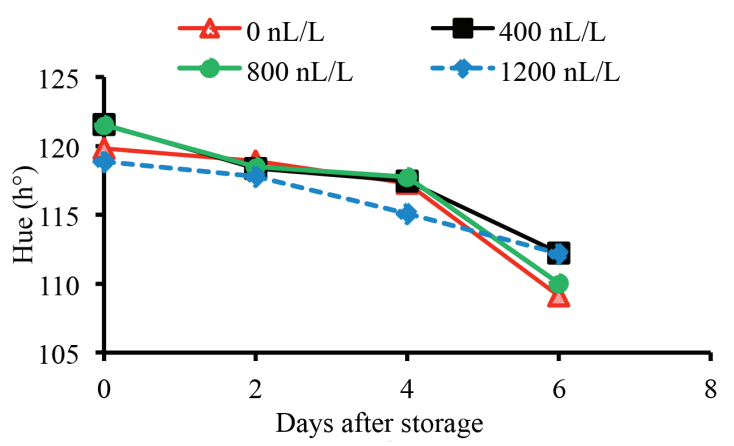

FIGURE 3. Lightness (a), chrome (b) dan hue (c) of soursop treated with 1-MCP during day after storage

Determination of antioxidant activities of soursop extracts were carried out using DPPH (1,1-diphenyl-2picrylhydrazyl) scavenging activity. The DPPH scavenging activity in control fruits increased over the storage period with the highest values recorded on day $6(84.20 \%)$ and the lowest on day 0 (43.54\%) (Figure 4(b)). All soursop treated with 1-MCP showed a relatively lower DPPH scavenging percentage than that in control. However, these 1-MCP treated fruits did gradually decrease during storage period. This result is in agreement with previous studies that showed DPPH scavenging activity was steady or increased during storage period (Hoang et al. 2011; Watkin 2015).

As shown in Figure 4(c), total phenolic content in soursop decreased at the end of storage period except 800 $\mathrm{nL} / \mathrm{L} 1-\mathrm{MCP}$ treated fruit. This is in agreement with the general observations by Aziz and Yusof (1994), Oliviera et al. (1994) and Paull (1982) who detected a decrease in the concentrations of the total phenolic when soursop fruit was fully ripe. 1-MCP markedly inhibited the decline 

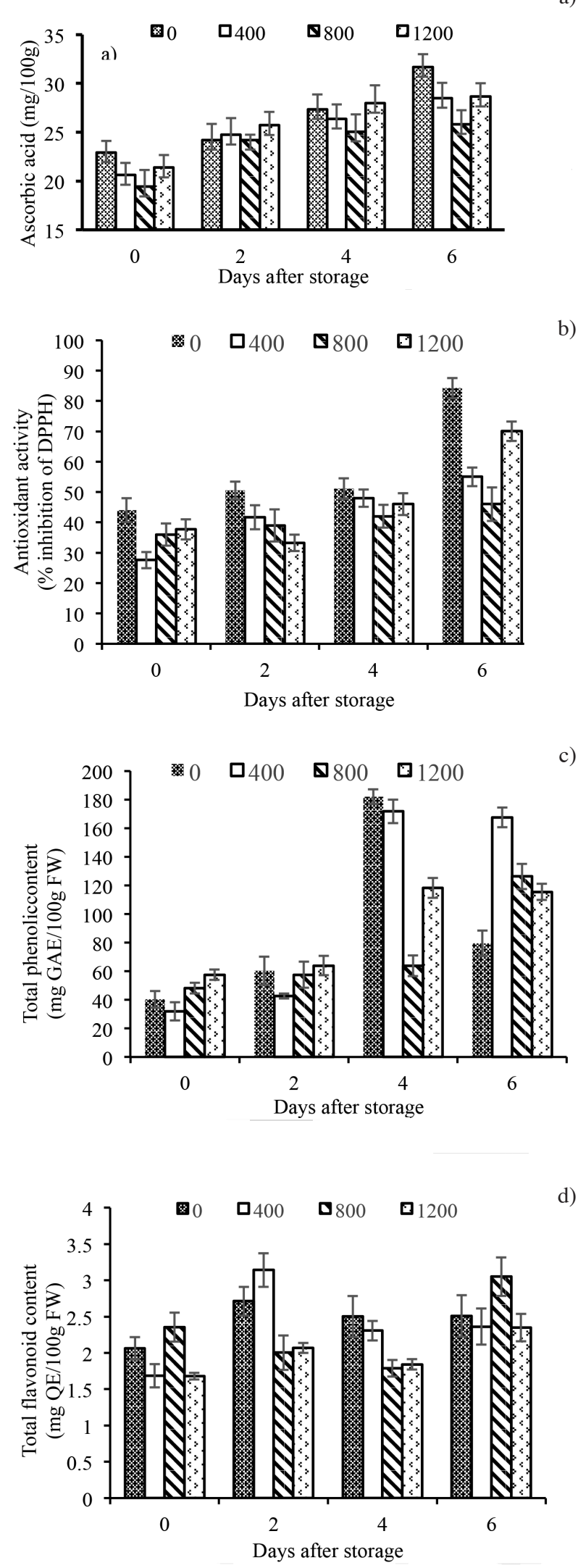

FIGURE 4. Ascorbic acid (a) antioxidant activity (b) total phenolic content (c) total flavonoid content (d) of soursop treated with 1-MCP during day after storage. Vertical bars represent s.e $(n=3)$ a)

b)

c)

d)

ethylene production, thus the total phenolic contents were maintained higher levels throughout the storage period compared with the control fruit. The results suggested that 400, 800 and $1200 \mathrm{~nL} / \mathrm{L}$, respectively, 1-MCP slowed down the degradation of total phenolic content in soursop. The results were consistent with other studies. Cao et al. (2011) reported a slowing down scenario in total phenolic content due to the effect of 1-MCP in loquat. Fawbush et al. (2009) showed that total phenolic content for the control were higher than $1 \mu \mathrm{L} / \mathrm{L}$ 1-MCP treated 'Empire' apples in air and controlled atmosphere storage during 5 months' storage periods. In contrast, an increase in total phenolic content during storage have been previously reported for Mexican cultivar soursop fruits treated with 1-MCP and stored at $16^{\circ} \mathrm{C}$ (Moreno-Hernández et al. 2014). In addition, this is in line with Pushp et al. (2013), who pointed out the differences between the extraction procedures for extraction of bioactive compounds which influenced the results.

The trend of total flavonoid content was instability during storage period at ambient condition for all treated fruits (Figure 4(d)). Unlike finding by Selcuk and Erkan (2015) reported that total phenolics and total flavonoids of 1-MCP treated medlars fruit were decreased when storage at $20^{\circ} \mathrm{C}$ with $90 \% \pm 2 \%$ relative humidity (RH) for ten days. While, the application of 1-MCP significantly retarded the decline of TFC during ripening on mango cv Kent (Dharini et al. 2011).

\section{CONCLUSION}

Generally, the study proved that the application of 1-MCP on local cultivar soursop successfully showed had significant effect on postharvest quality including maintaining the firmness, $\mathrm{pH}, \mathrm{TA}, \mathrm{SSC}$ and retain the green colour peel. All the 1 -MCP treated fruits at $15^{\circ} \mathrm{C} \pm 3^{\circ} \mathrm{C}$ for 24 hours able to ripen at ambient conditions by day 6 after storage. Soursop treated at different $1-\mathrm{MCP}$ concentrations $(0,400,800$ and $1200 \mathrm{~nL} / \mathrm{L}$ ) showed that fruit treated with $400 \mathrm{~nL} / \mathrm{L}$ had better ripe fruit quality. Therefore, $1-\mathrm{MCP}$ concentration at $400 \mathrm{~nL} / \mathrm{L}$ will be the appropriate concentration to be chosen for further studies. However, antioxidant activity, total phenolic content, and total flavonoid content of fruits from all treatments were found to be inconsistent during storage.

\section{ACKNOWLEDGEMENTS}

This research was support by the Geran Putra (No. 9454400) 2015/2017 Universiti Putra Malaysia.

\section{REFERENCES}

Abdi, N., McGlasson, W.B., Holford, P., Williams, M. \& Mizrahi, Y. 1998. Responses of climacteric and suppressed-climacteric plums to treatment with propylene and 1-methylcyclopropene. Postharvest Biology and Technology 14(1): 29-39.

Agius, F., González-Lamothe, R., Caballero, J.L., MuñozBlanco, J., Botella, M.A.\& Valpuesta, V. 2003. Engineering increased vitamin $\mathrm{C}$ levels in plants by overexpression of a 
D-galacturonic acid reductase. Nature Biotechnology 21(2): 177-181.

Ahmad, A., Mohd Ali, Z. \& Zainal, Z. 2013. Delayed softening of papaya (Carica papaya L. cv. 'Sekaki') fruit by 1-methylcyclopropene (1-MCP) during ripening at ambient and low temperature storage conditions. Australian Journal of Crop Science 7(6): 750-757.

Aziz, P.A. \& Yusof, S. 1994. Physico-chemical characteristics of soursop fruit (Annona muricata) during growth and development. ASEAN Food Journal 9: 147-150.

Barreca, D., Laganà, G., Ficarra, S., Tellone, E., Leuzzi, U., Galtieri,A. \& Bellocco,E. 2011. Evaluation of the antioxidant and cytoprotective proprieties of the exotic fruit Annona cherimola Mill. (Annonacceae). Food Research International 44: 2302-2310.

Benassi, G., Correa, G.A.S.F., Kluge, R.A. \& Jacomino, A.P. 2003. Shelf life of custard apple treated with 1-methylciclopropeneAn antagonist to the ethylene action. Brazilian Archives of Biology and Technology 46: 115-119.

Blanke, M.M. 1991. Respiration of apple and avocado fruits. Postharvest News Information 2: 429-436.

Blankenship, S.M. \& Dole, J.M. 2003. 1-Methylcyclopropene: A review. Postharvest Biology and Technology 28: 1-25.

Bruinsma, J. \& Paull, R.E. 1984. Respiration during postharvest development of soursop fruit, Annona muricata L. Plant Physiology 76(1): 131-138.

Brummell,D.A.\& Harpster, M.H. 2001. Cell wall metabolism in fruit softening and quality and its manipulation in transgenic plants. Plant Molecular Biology 47: 311-340.

Brummell, D.A. 2006. Cell wall disassembly in ripening fruit. Functional Plant Biology 33(2): 103-119.

Cao, S., Zheng, Y. \& Yang, Z. 2011. Effect of 1-MCP treatment on nutritive and functional properties of loquat fruit during cold storage. New Zealand Journal of Crop and Horticultural Science 39(1): 61-70.

Dharini Sivakumar, Yuming Jiang \& Elhadi M. Yahia. 2011. Maintaining mango (Mangifera indica L.) fruit quality during the export chain. Food Research International 44(5): 1254-1263.

Ding, P. \& Ong, P.T. 2010. Extending 'Kampuchea' guava shelflife at $27^{\circ} \mathrm{C}$ using 1-Methylcyclopropene. International Food Research Journal 17: 63-69.

Ding, P. \& Darduri, K.B. 2009. Responses of Musa AAA Berangan to 1-methylcyclopropene. Pertanika Journal of Tropical Agricultural Science 32(2): 125-132.

DOA. 2015. Fruit Crops Statistic Malaysia. Putrajaya: Department of Agriculture. p. 26.

Dong, L., Zhou, H.W., Sonego, L., Lers, A. \& Lurie, S. 2001. Ethylene involvement in the cold storage disorder of 'Flavortop' nectarine. Postharvest Biology and Technology 23(2): 105-115.

Espinosa, I., Ortiz, R.I., Tovar, B., Mata, M. \& Montalvo, E. 2013. Physiological and physicochemical behavior of soursop fruits refrigerated with 1-methylcyclopropene. Journal of Food Quality 36(1): 10-20.

Fawbush, F., Nock, J.F. \& Watkins, C.B. 2009. Antioxidant contents and activity of 1-Methylcyclopropene (1-MCP) treated 'Empire' apples in air and controlled atmosphere storage. Postharvest Biology and Technology 52: 30-37.

Gang, C., Li, J., Chen, Y., Wang, Y., Li, H., Pan, B. \& Odeh, I. 2015. Synergistic effect of chemical treatments on storage quality and chilling injury of honey peaches. Journal of Food Processing and Preservation 39: 1108-1117.
Geurts, F. 1981. Annonaceous Fruits.Amsterdam: Royal Tropical Institute. p. 16.

González-Agüero, M., Tejerina Pardo, L., Zamudio, M.S., Contreras, C., Undurraga, P. \& Defilippi, B.G. 2016. The unusual acid-accumulating behavior during ripening of cherimoya (Annona cherimola Mill.) is linked to changes in transcription and enzyme activity related to citric and malic acid metabolism. Molecules 21(5): E398.

Hofman, P.J., Jobin-Décor, M., Meiburg, G.F., Macnish, A.J. \& Joyce, D.C. 2001. Ripening and quality responses of avocado, custard apple, mango and papaya fruit to 1-methylcyclopropene. Australian Journal of Experimental Agriculture 41: 567-572.

Hoang, N.T., Golding, J.B. \& Wilkes, M.A. 2011. The effect of postharvest 1-MCP treatment and storage atmosphere on 'Cripps Pink' apple phenolics and antioxidant activity. Food Chemistry 127(3): 1249-1256.

Jeong, J., Huber, D.J. \& Sargent, S.A. 2002. Influence of 1-methylcyclopropene (1-MCP) on ripening and cell-wall matrix polysaccharides of avocado (Persea americana) fruit. Postharvest Biology and Technology 25(3): 241-256.

Jiménez, V.M., Gruschwitz, M., Schweiggert, R.M., Carle, R. \& Esquivel, P. 2014. Identification of phenolic compounds in soursop (Annona muricata) pulp by high-performance liquid chromatography with diode array and electrospray ionization mass spectrometric detection. Food Research International 65: 42-46

Kader, A.A. 1997. Fruit maturity, ripening, and quality relationships. Acta Horticulturae 485: 203-208.

Khan, A.S. \& Singh, Z. 2007. 1-MCP regulates ethylene biosynthesis and fruit softening during ripening of 'Tegan Blue' plum. Postharvest Biology and Technology 43: 298306.

Lafka, T.I., Sinanoglou, V. \& Lazos, E.S. 2007. On the extraction and antioxidant activity of phenolic compounds from winery wastes. Food Chemistry 104(3): 1206-1214.

Lalel, H.J.D., Singh, Z. \& Tan, S.C. 2003. The role of ethylene in mango fruit aroma volatiles biosynthesis. The Journal of Horticultural Science and Biotechnology 78(4): 485-496.

Li, C., Shen, W., Lu, W., Jiang, Y., Xie, J. \& Chen, J. 2009. 1-MCP delayed softening and affected expression of XET and EXP genes in harvested cherimoya fruit. Postharvest Biology and Technology 52: 254-259.

Li, X.W., Cao, S.F., Zheng, Y.H. \& Sun, A.P. 2011. 1-MCP suppresses ethylene biosynthesis and delays softening of 'Hami' melon during storage at ambient temperature. Journal of the Science of Food and Agriculture 91: 2684-2688.

Lima, M.A.C., Alves, R.E. \& Filgueiras, H.A.C. 2010. Respiratory behavior and softening of soursop fruit (Annona muricata L.) after postharvest treatments with wax and 1-methylcyclopropene. Ciencia e Agrotecnologia 34(1): 155-162.

Lima, M.A.C., Alves, R.E. \& Filgueiras, H.A.C. 2006. Changes related to softening of soursop during postharvest maturation. Pesquisa Agropecuaria Brasileira 41(12): 1707-1713.

Liu, H., Cao, J. \& Jiang, W. 2015. Changes in phenolics and antioxidant property of peach fruit during ripening and responses to 1-methylcyclopropene. Postharvest Biology and Technology 108: 111-118.

Lohani, S., Trivedi, P.K. \& Nath, P. 2004. Changes in activities of cell wall hydrolases during ethylene-induced ripening in banana: Effect of 1-MCP,ABA and IAA. Postharvest Biology and Technology 31(2): 119-126. 
Loizzo, M.R., Tundis, R., Bonesi, M., Menichini,F., Mastellone, V., Avallone, L. \& Menichini, F. 2012. Radical scavenging, antioxidant and metal chelating activities of Annona cherimola mill. (Cherimoya) peel and pulp in relation to their total phenolic and total flavonoid contents. Journal of Food Composition and Analysis 25(2): 179-184.

Moreno-Hernández, C.L., Sáyago-Ayerdi, S.G., García-Galindo, H.S., Mata-Montes De Oca, M. \& Montalvo-González, E. 2014. Effect of the application of 1-methylcyclopropene and wax emulsions on proximate analysis and some antioxidants of soursop (Annona muricata L.). The Scientific World Journal 2014: 896853.

Oliviera, S., Guerra, N.B., Sucupira Maciel, M.I. \& Souza Livera, A.V. 1994. Polyphenoloxidase activity, polyphenols concentration and browning intensity during soursop (Annona muricata L.) maturation. Journal of Food Science 59(5): 1050-1052.

Özkaya, O., Yildirim, D., Dündar,Ö. \& Tükel, S.S. 2016. Effects of 1-methylcyclopropene (1-MCP) and modified atmosphere packaging on postharvest storage quality of nectarine fruit. Scientia Horticulturae 198: 454-461.

Paull, R.E. 1982. Postharvest variation in composition of soursop (Annona muricata L.) fruit in relation to respiration and ethylene production. Journal of American Society of Horticultural Science 107: 582-585.

Paull, R.E., Deputy, J. \& Chen, N.J. 1983. Change in organic acids, sugars, and headspace volatile during fruit ripening of soursop (Annona muricata L.). Journal of American Society of Horticultural Science 108: 931-934.

Piriyavinit, P., Ketsa, S. \& Doom, V.W.G. 2011. 1-MCP extends the storage and shelf life of mangosteen (Garcinia mangostana L.) fruit. Postharvest Biology and Technology 6: $15-20$

Pongprasert, N. \& Srilaong, V. 2014. A novel technique using 1-MCP microbubbles for delaying postharvest ripening of banana fruit. Postharvest Biology and Technology 95: 42-45.

Pushp, P., Sharma, N., Joseph, G.S. \& Singh, R.P. 2013. Antioxidant activity and detection of (-)epicatechin in the methanolic extract of stem of Tinospora cordifolia. Journal of Food Science and Technology 50(3): 567-572.

Ranganna, S. 1977. Manual of Analysis of Fruits and Vegetables Products. New Delhi: McGraw Hill Pub. Co. pp. 135-141, 484-572.

Razali, M.,Ali,Z.M. \& Othman, R. 2012.1-Methylcyclopropene (1-MCP) and heat treatment affected weight loss and ethylene biosynthesis of 'Sekaki' papaya stored at low temperature. Acta Horticulturae 1012: 375-381.

Razzaq, K., Singh, Z., Khan, A.S., Khan, S.A.K.U. \& Ullah, S. 2016. Role of 1-MCP in regulating 'Kensington Pride' mango fruit softening and ripening. Plant Growth Regulation 78(3): 401-411.

Selcuk, N. \& Erkan, M. 2015. The effects of 1-MCP treatment on fruit quality of medlar fruit (Mespilus germanica L. cv. Istanbul) during long term storage in the palliflex storage system. Postharvest Biology and Technology 100: 81-90.

Sisler, E.C. \& Serek, M. 1997. Inhibition of ethylene responses in plants at the receptor level: Recent development. Plant Physiology 100: 577-582.

Thaipong, K., Boonprakob, U., Crosby, K., Cisneros-Zevallos, L. \& Byrne, H.D. 2006. Comparison of ABTS, DPPH, FRAP and ORAC assays for estimating antioxidant activity from guava fruit extracts. Journal of Food Composition and Analysis 19: 669-675.
Vanoli, M., Grassi, M. \& Rizzolo, A. 2016. Ripening behavior and physiological disorders of 'Abate Fetel' pears treated at harvest with 1-MCP and stored at different temperatures and atmospheres. Postharvest Biology and Technology 111: 274-285.

Vishnu Prasanna, K.N., Sudhakar Rao, D.V. \& Krishnamurthy, S. 2000. Effect of storage temperature on ripening and quality of custard apple (Annona squamosa L.) fruits. The Journal of Horticultural Science and Biotechnology 75(5): 546-550.

Watkins, C.B. 2015. Advances in the use of 1-MCP. In Advances in Postharvest Fruit and Vegetable Technology, edited by Wills, R.B.H. \& Golding, J. Boca Raton: CRC Press. pp. $117-146$.

Wills, R.B.H., McGlasson, W.B., Graham, D. \& Joyce, D.C. 2007. Post-Harvest. An Introduction to the Physiology and Handling of Fruits, Vegetables and Ornamentals. Sydney: UNSW Press.

Wills, R.B.H., McGlasson, W.B., Graham, D. \& Joyce, D.C. 1998. Postharvest: An Introduction to the Physiology and Handling of Fruit, Vegetables and Ornamentals. Wallingford: CAB International. pp. 262.

Woolf, A.B., Requejo-Tapia, C., Cox, K.A., Jackman, R.C., Gunson, A., Arpaia, M.L. \& White, A. 2005. 1-MCP reduces physiological storage disorders of 'Hass' avocados. Postharvest Biology and Technology 35: 43-60.

Worrell, D.B., Carrington, C.M.S.\& Huber, D.J. 1994. Growth, maturation and ripening of soursop (Annona muricata L.) fruit. Scientia Horticulturae 57(1-2): 7-15.

Zhang, Z., Huber, D.J. \& Rao, J. 2011. Ripening delay of midclimacteric avocado fruit in response to elevated doses of 1-methylcyclopropene and hypoxia-mediated reduction in internal ethylene concentration. Postharvest Biology and Technology 60(2): 83-91.

Zhu, X., Shen, L., Fu, D., Si, Z., Wu, B., Chen, W. \& Li, X. 2015. Effects of the combination treatment of 1-MCP and ethylene on the ripening of harvested banana fruit. Postharvest Biology and Technology 107: 23-32.

Lem Ming Siang* \& Mahmud Tengku Muda Mohamed Institute of Tropical Agriculture and Food Security

Universiti Putra Malaysia

43400 UPM Serdang, Selangor Darul Ehsan Malaysia

Phebe Ding \& Mahmud Tengku Muda Mohamed

Department of Crop Science

Faculty of Agriculture

Universiti Putra Malaysia

43400 UPM Serdang, Selangor Darul Ehsan

Malaysia

*Corresponding author; email: lemmsdoa@gmail.com

Received: 29 June 2018

Accepted: 7 December 2018 